УДК664.661.3, DOI 10.31210/visnyk2018.04.11

(C) 2018

\author{
Бараболя О. В., кандидат сільськогосподарських наук, \\ Калашник О. В., кандидат технічних наук, \\ Мороз С. Е., кандидат педагогічних наук, \\ Жемела Г. П., доктор сільськогосподарських наук \\ Полтавська державна аграрна академія
}

Юдічева О. П. кандидат технічних наук

Київський національний університет будівництва і архітектури

Сергієнко О. В. кандидат сільськогосподарських наук

Інститут овочівництва і баштанництва НААН

\title{
ВИКОРИСТАННЯ НАПІВФАБРИКАТІВ ГАРБУЗА ДЛЯ ЗБАГАЧЕННЯ ХЛІБА ПШЕНИЧНОГО
}

\section{Рещензент - доктор сільськогосподарських наук, професор В. М. Тищенко}

Одним із пріоритетних завдань сучасного хлібопечення є випуск продукції, яка відрізняється покращеними споживними властивостями.

Для виконання иього завдання необхідно максимально залучити в господарський обіг місиеві сировинні ресурси рослинного походження, розробити оптимальні способи їх переробки з метою отримання біологічно иінних напівфабрикатів, щзо стане поштовхом для виробництва функціональних продуктів харчування.

Щоденне споживання хліба дає нам всі підстави вважати його продуктом харчування, шчо має першочергове значення, тому не випадково у статті була здійснена спроба доповнити рецептуру хліба пшеничного для надання йому істотно нових споживних властивостей, які відповідали б сучасним вимогам щзодо харчування.

Ключові слова: хліб, гарбуз, сорт, напівфабрикат, пробне випікання, збагачення.

Постановка проблеми. Цікавим напрямом під час створення збагачених харчових продуктів $\epsilon$ використання сировини, яка $\epsilon$ природним джерелом біологічно активних речовин і адаптована до травного раціону пересічного українця.

Поповнити баланс життєво важливих для людини макро- і мікронутрієнтів можливо за рахунок цінної високоврожайної культури - гарбуза.

Хоча в Україні обсяги вирощування та використання є досить низькими, гарбузи були і залишаються улюбленою овочевою культурою багатьох українців.

За останні роки в країнах $€ С$ значно збільшилось виробництво гарбуза і досягло в таких країнах як Італія - 350 тис. т, Франція, Німеччина 70 тис. т, Іспанія -50 тис. т [1].

Гарбуз відноситься до числа цінних овоче- баштанних культур, плоди і насіння якого мають важливе значення як харчові продукти, що забезпечують дієтичне (завдяки високому вмісту каротину, цукрів, мікроелементів, харчових волокон, крохмалю) і лікувально-профілактичне харчування (знижують ризик серцево-судинних, онкологічних i шлунково-кишкових захворювань) [2-4].

Гарбуз складається 3 85-94 \% води. Вуглеводів у складі м'якушу гарбуза 8-12\%. Вміст цукру в основних сортах $-4-8 \%$, а в окремих мускатних сортах гарбуза цей показник може становити до $14 \%$. Плоди гарбуза містять від 2,5 до $16 \%$ крохмалю, який під час зберігання переходить в розчинні цукри. Клітковини у гарбузі 1,2 \%, пектинів - 0,7-1,2\%, органічних кислот $-0,1 \%$. Гарбуз - справжня скринька мінеральних сполук.

Він містить у достатній кількості кальцій, калій, фосфор, залізо, мідь, фтор і цинк. У гарбузовому м'якуші дуже багато каротину, у гарбузі містяться вітаміни групи $\mathrm{B}, \mathrm{C}, \mathrm{E}, \mathrm{D}, \mathrm{PP}$, а також рідкісний вітамін Т [5].

Таким чином, використання продуктів переробки плодів гарбуза (за рахунок їх цінного хімічного складу) надасть можливості для коригування рецептури хліба з метою одержання біологічно цінної продукції з вираженими лікувальнопрофілактичними властивостями.

Використання гарбуза різноманітне - від фармацевтичної до харчової промисловості. У харчовій промисловості гарбуз знайшов своє використання у різних видах - як у натуральному, так і у вигляді напівфабрикатів.

Перевагу надають різноманітним напівфабрикатам, які краще зберігати, транспортувати, а 


\section{СІЛЬСЬКЕ ГОСПОДАРСТВО. РОСЛИННИЦТВО}

також зручно використовувати.

Отже, дослідження якості напівфабрикатів як сировини для збагачення хліба важливими макро- і мікронутрієнтами з метою одержання продукції функціонального призначення $\epsilon$ актуальними.

Аналіз останніх досліджень і публікацій, у яких започтаковано розв'язання проблеми. Вітчизняний та світовий досвід свідчить про те, що одним iз шляхів ефективного поповнення недостатньої кількості вітамінів та мінеральних речовин, що надходять із традиційним раціоном, $\epsilon$ збагачення цими нутрієнтами продуктів масового споживання, і хліба зокрема.

Для цього необхідно в рецептурах хліба використовувати нетрадиційну сировину [6], яка може змінювати не тільки запах та аромат хліба, а й ще надати йому необхідних для людини властивостей, підвищити його харчову цінність.

До функційних інгредієнтів висувають особливі вимоги щодо відсутності здатності зменшувати харчову цінність продукту, безпечність 3 точки зору збалансованого харчування тощо [7]. Цим вимогам відповідають напівфабриками, виготовлені з гарбуза.

Для виготовлення напівфабрикатів використовують різні технологічні процеси, характеристика яких наведена нижче.

За повідомленням авторів [5, 8] було визначено та досліджено способи отримання пюре із гарбуза у сирому та відвареному вигляді. Для підтвердження можливості використання було здійснено пробні випічки хліба.

В Одеській національній академії харчових технологій науковцями [9] розглянуто можливості впровадження інтенсивних технологій, а саме застосування у тісті порошку із гарбуза, отриманого методом активаційної сушки для зменшення швидкості його приготування та максимального збереження вітаміну C.

Ці дані підтверджено у роботі [10], де досліджено хімічний склад фруктово-овочевих порошків, зокрема із гарбуза, і визначено їхні лікувально-дієтичні й профілактичні функції.

За даними, що містяться у роботі [11], виявлено, що сушений гарбуз може використовуватися у вигляді скибочок, шматочків, гранул або борошна.

У роботі [11] досліджено використання борошна із гарбуза як функціональної основи під час розробки комплексного хлібопекарського поліпшувача тіста. Встановлено, що це борошно має вплив на розтяжність клейковини, збільшує бродильну активність хлібопекарських дріжджів, сприяє покращенню якісних характеристик хліба.

У роботах $[5,8]$ підтверджено можливість використання визначених сортів гарбуза у складі рецептури булочних виробів. Проте не всі сорти гарбузів можна використовувати для хлібопечення.

За свідченнями науковців [12], у харчовій промисловості використовують різні сорти гарбузів.

Відомо, що на теренах України селекцією гарбуза займаються Інститут овочівництва і баштанництва НААН України та Дніпропетровська дослідна станція овочівництва та баштанництва.

Ці науково-дослідні підприємства здійснюють розробку та впровадження нових сортів гарбуза.

Одним із новостворених сортів $є$ гарбуз мускатний Доля. За даними селекціонерів, він має такі показники:

- вміст сухої речовини в плодах - 7,5-10,6 \%,

- цукрів - 5,0-6,5\%,

- каротину - 14,6-19,2 мг\%.

Для встановлення можливостей використання напівфабрикатів для обрання оптимального сорту було проведено порівняння 3 іншими закордонними високопродуктивними сортами.

Тому були обрані такі сорти зі встановленими характеристиками:

- сорт гарбуза мускатного Доля - пізньостиглий (120-126 діб), плоди перехватки, гладенькі середнього розміру, масою 5-9 кг; забарвлення кори плода коричневе, характерне для виду, без малюнку, плоди із восковим нальотом; м'якоть яскраво-помаранчева, середньощільна, солодка; урожайність плодів - 28-30 т/га;

- сорт гарбуза крупноплідного Рожевий банан - середньостиглий (90-110 діб); плоди веретеноподібні масою 5-18 кг, забарвлення кори блідорожевого кольору; м'якоть солодка, насиченого помаранчевого кольору, щільна у м'якоті практично відсутні волокна;

- сорт гарбуза твердокорого Даная - сорт середньостиглий (100-110 діб); плоди кулясті помаранчево-зеленого забарвлення масою 5-10 кг; м'якоть жовтого кольору, насіння темно-зелені, без твердої скоринки урожайність плодів 40-60 т/га.

Мета досліджень - проведення аналітичних досліджень для встановлення можливостей використання напівфабрикатів гарбуза для збагачення хліба пшеничного, яке буде відбуватися за рахунок пектинових речовин та вітамінів (особливо бета-каротину, вітаміну С), що містяться у гарбузі.

Це дослідження буде підтверджено проведенням пробного випікання хліба пшеничного з використанням різних напівфабрикатів та порів- 


\section{СІЛЬСЬКЕ ГОСПОДАРСТВО. РОСЛИННИЦТВО}

няння отриманих результатів.

Для досягнення окресленої мети було потрібно виконати наступні завдання:

- приготувати напівфабрикати (сок і пюре) iз гарбузів різних сортів із використанням різних технологій;

- здійснити пробне випікання хліба пшеничного 3 різними напівфабрикатами (контроль - хліб пшеничний, виготовлений за традиційною рецептурою);

- провести оцінку якості дослідних зразків за органолептичними показниками для встановлення впливу доданих напівфабрикатів на зміни зовнішнього вигляду, кольору і форми хліба.

Матеріали і методи досліджень. Як об'єкти дослідження були використані плоди гарбузів, показники яких наведено в таблиці 1, та одержані з них напівфабрикати - сік і пюре, виготовлені за допомогою різних технологій.

Таким чином, під час проведення досліджень було встановлено, що їстівна частка гарбузів залежить від їх виду і сорту, зокрема у нашому випадку вона була найбільша у сорту Доля $(76,6 \%)$.

Окрім того у описі цього сорту зазначено, що це сорт столовий, для промислової переробки; плоди добре зберігаються.

Для оцінювання показників якості хліба пшеничного, збагаченого напівфабрикатами гарбуза, було використано такі методи дослідження:

- органолептичні - форма, поверхня і колір,

- гравіметричні - маса плодів, вихід частин гарбуза.

Результати досліджень. Для отримання напівфабрикатів використали:

- технологію приготування соку 3 плодів гарбуза, яка включала такі операції: мийка гарбуза, інспекція, видалення плодоніжки, очищення та різання, видалення насіння, інспекція, ополіскування, різання, протирання;

- технологію приготування пюре $з$ плодів гарбуза, запропоновану у роботі [8], яка складалася iз таких операцій: інспекція плодів на цілісність їх плодів, травмованість, ураження шкідниками та патогенними мікроорганізмами; їх мийка та бланшування; видалення плодоніжки, очищення та видалення насіння, нарізання та протирання пюре;

- технологію приготування пюре 3 плодів гарбуза за допомогою запікання - являє собою схожий $з$ попереднім процес, у якому перед операцією протирання відбувається операція запікання у духовій шафі протягом 15-20 хвилин.
Для визначення впливу напівфабрикатів, виготовлених із гарбуза, на показники якості хліба пшеничного проводили пробне випікання за загальноприйнятою методикою [13] наукових досліджень в акредитованій лабораторії якості зерна Полтавської державної аграрної академії.

У процесі виробництва хліба використовували наступні інгредієнти та рецептуру:

- борошно пшеничне вищого сорту (300 г);

- дріжджі пресовані (15 г);

- сіль кам'яна (4 г);

- гарбузовий сік (250 мл) або пюре з подрібненої м'якоті гарбуза (245-250 г), або пюре із запеченої м’якоті гарбуза (230-250 г).

Як бачимо, у рецептурі хліба пшеничного не використовували цукор. Його повністю замінюють цукри, що містяться у напівфабрикатах, виготовлених із гарбуза.

У результаті проведення пробного випікання отримали зразки хліба (рис. 1).

Органолептична оцінка якості хліба із пшеничного борошна проводилась згідно з ДСТУ 7517 : 2014 «Хліб із пшеничного борошна. Загальні технічні умови» [14].

Показники (форма, поверхня і колір) оцінювали оглядом усього хліба.

За результатами досліджень встановлено, що дослідні зразки хліба мають наступні характеристики:

- форма відповідає формі, у якій проводили випікання, $з$ дещо випуклою верхньою скоринки без бокових випливів; правильна, прямокутна, не розпливчаста;

- поверхня у зразків 1, 3 та 4 гладка, без забруднення, у зразка 2 - шорстка, без великих тріщин і великих підривів;

- колір у зразка 1 - світло-жовтий без підгорілості, скоринка - світло-коричнева; зразки 2, 3, 4 відрізнялися інтенсивним забарвленням золотисто-жовто-помаренчевого кольору, верхівка - світло-коричнева, без підгорілостей.

Отже, аналізом літературних джерел та пробним випіканням зразків хліба пшеничного, що містять напівфабрикати гарбуза (гарбузовий сік i пюре), була доведена можливість їх використання в індустрії хлібопечення.

Зокрема, всі дослідні зразки хліба мали правильну форму, поверхню без тріщин і підривів, приємний колір.

Неприпустимих дефектів зовнішнього вигляду і кольору не виявлено. 


\section{1. Характеристика об'єктів дослідження}

\begin{tabular}{|c|c|c|c|c|}
\hline Сорт / вид & Зовнішній вигляд & $\begin{array}{c}\text { Частка } \\
\text { насіння, \% }\end{array}$ & $\begin{array}{c}\text { Частка } \\
\text { шкірки, \% }\end{array}$ & $\begin{array}{c}\text { Частка, } \\
\text { м'якоті, \% }\end{array}$ \\
\hline $\begin{array}{c}\text { Доля } \\
\text { (мускатний }\end{array}$ & 5,5 & 17,9 & 76,6 \\
\hline $\begin{array}{c}\text { Рожевий банан } \\
\text { (крупноплідний) }\end{array}$ & 10,9 & 21,8 & 67,2 \\
\hline $\begin{array}{c}\text { Даная } \\
\text { (твердокорий) }\end{array}$ & & 5,2 & 25,1 & 69,7 \\
\hline
\end{tabular}

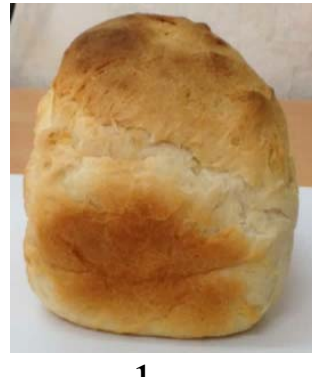

1

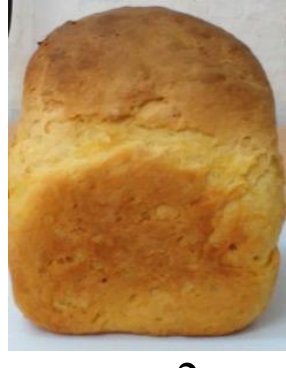

2

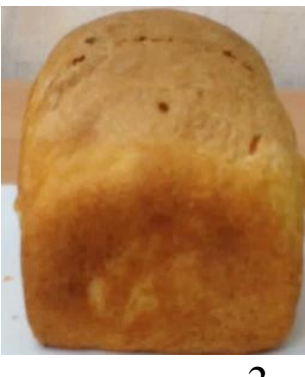

3

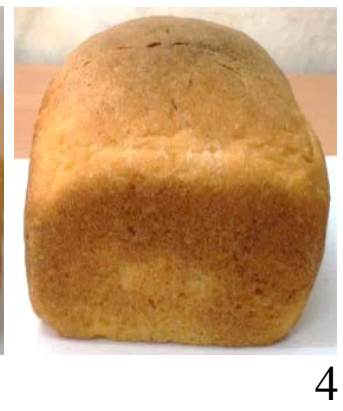

4

Рис. 1. Фотографічне зображення отриманих зразків хліба пшеничного:

1 -контрольний; 2 - із гарбузовим соком; 3 - із пюре з подрібненої м'якоті гарбуза; 4 - із пюре із запеченої м'якоті гарбуза

Висновок. Таким чином, використання гарбузів як мускатних (Доля), такйі інших сортів (Рожевий банан і Даная) для приготування біологічно цінних напівфабрикатів (соку і пюре) з метою додавання їх у рецептуру під час виробництва високоякісного хліба є перспективним напрямом у хлібопекарській промисловості для

\section{БІБЛІОГРАФІЯ}

1. Шершнева О. М., Овчинникова Р. И. Использование тыквы в производстве хлебобулочних изделий https://cyberleninka.ru/article/n/ispolzovanie-tykvyv-proizvodstve-hlebobulochnyh-izdeliy. (дата звернення 22.10 .2018 р.). - Назва з екрана.

2. Михалев В. Ю. Особенности производства семян тыквы на фармакологические цели с применением механизированной уборки в условиях Волгоградского Заволжья : автореф. дис. на соискание науч. степениканд. с.-х. наук : спец. 06.01.06 «Лекарственные и эфирно-масличные створення хлібобулочних виробів із направленими властивостями.

Після випікання зразків хліба пшеничного планується проведення досліджень із визначення органолептичних, фізико-хімічних та мікробіологічних показників якості.

культуры» ВНИИО, М., 2003. - 23с.,

3. Теханович Г. А. Генофонд бахчевых культур и его использование в селекции : автореф. дис. на соискание науч. степнени д-ра с.-х. наук : спец. 06.01.05 «Селекція і насінництво сільськогосподарських рослин»/Г. А. Теханович. - СПб., 2004. -32 c.

4. Hirayama T. Greeny ellow vegetables for human healthwith special reference tocarcer prevention / T. Hirayama // J. Japan. Soc. Hort. Sci. - 1995 -№ 63. - P. 965. 


\section{СІЛЬСЬКЕ ГОСПОДАРСТВО. РОСЛИННИЦТВО}

5. Ухина Е. Ю., Мараева О. Б. Исследование возможностей использования тыквенного пюре в хлебопечении http://rosfood.info/upload/iblock/5cf/50-52.pdf (дата звернення 22.10.2018 р.). - Назва з екрана.

6. Коршенко Л. О. Стабилизация качества хлеба из пшеничной муки с низкими хлебопекарными свойствами [Електронний ресурс]. - URL : https://naukovedenie.ru/PDF/115TVN614.pdf. (дата звернення 22.10.2018 р.). - Назва з екрана.

7. Сокол Н. В., Храмова Н. С. Использование богатого пектином растительного сырья в хлебопекарном производстве https://naukovedenie.ru /PDF/115TVN614.pdf. (дата звернення 22.10.2018 p.). - Назва з екрана.

8. Использование пюре из тыквы в пищевой промышленности хлебопечении [Електронний ресурс]. - URL : https://cyberleninka.ru/article/v/ ispolzovaniepyure-iz-tykvy-v-pischevoy-promyshlennosti (дата звернення 22.10.2018 р.). - Назва з екрана.

9. Влияние тыквенного порошка на физикомеханические свойства замороженного теста для пиццы [Електронний ресурс]. - URL : file://C:/Users/1/Downloads/Khnit 2010_1

17\%20(2).pdf. (дата звернення $2 \overline{2} \cdot 10.2 \overline{0} 1 \overline{8}$ р.). - Назва $з$ екрана.

10. Химический состав и лечебно-диетические и профилактические функции плодоовощных порошков, добавляемых в хлебобулочные изделия из пшеничной муки [Електронний ресурс]. URL : https://alley-science.ru/domains_data/files/

\section{ANNOTATION}

Barabolia O. V., Kalashnyk O. V., Moroz S. E., Zhemela G. P., Yudicheva O. P., Serhienko O. V. The use of pumpkin semi-product for wheat bread enrichment.

Use of raw material which is a natural source of biologically active substances and adapted to the digestive ration of ordinary Ukrainians in order to enrich food products is an interesting problem to consider. It is possible to supplement the balance of vitally important for a person macro- and micronutrients at the expense of valuable highyielding crop - pumpkin. Although in Ukraine the volume of cultivation and use is rather low, pumpkins have been and remain favorite vegetable crop of many Ukrainians.

Pumpkin using varies from the pharmaceutical to the food industry. In food industry pumpkin can be used in the natural form as well as in the form of semi-products. The advantage is given to a variety of semi-finished products which are better stored, transported and used. So, study of semi-finished products quality as a raw material for the journal_may2017/himicheskiy\%20sostav\%20i\%201 echebno-

dieticheskie\%20i\%20profilakticheskie\%20funkcii\% 20plodoovoshnyh\%20poroshkov,\%20dobavlyaemy h\%20v\%20hlebobulochnye\%20izdeliya\%20iz\%20p shenichnoy\%20muki.pdf. (дата звернення 22.10.2018 р.). - Назва з екрана.

11. Гутий Б. В., Гачак Ю. Р., Ваврисевич Я. С., Наговська В. О. Вплив кріопорошку «Гарбуз» на технологію сиркових мас / Східно-європейський журнал передових технологій. - 2017. - №2/10 (86). - C. 20-24.file:///C:/Users/1/Downloads/98194212563-1-PB.pdf. (дата звернення 22.10.2018 р.). Назва з екрана.

12. Перспективи використання гарбуза в харчовій промисловості [Електронний ресурс]. Режим доступу: URL : http://dspace.nuft.edu. ua/jspui/bitstream/123456789/10558/1/Prospects \%20of\%20a\%20pumpkin.pdf. (дата звернення 22.10.2018 р.). - Назва з екрана.

13. Жемела Г.П., Шемавньов В.І., Маренич M. М., Олексюк O.M. Технологія зберігання та переробки продукції рослинництва: Навчальний посібник. - Дніпропетровськ, 2005, 248 с.

14. ДСТУ 7517:2014 Хліб із пшеничного борошна. Загальні технічні умови [Електронний ресурс]. URL : http://online.budstandart.comua/catalog/doc-page. html?id_doc=77546 (дата звернення 22.10.2018 р.). Назва 3 екрана.

enrichment of bread with important macro- and micronutrients in order to obtain functional products is important and urgent.

One of the priorities of the modern bakery is output of products which are characterized by improved consumer characteristics. To accomplish this task, it is necessary to maximally involve local raw materials of vegetable origin in the economic circulation as well as to develop the optimal methods of their processing in order to obtain biologically valuable semi-finished products. This will be an impuls for the production of functional food products. Daily consumption of bread gives us every reason to consider it to be a food product of high priority. In view of this, the article has attempted to supplement the wheat bread formula to provide it with substantially new consumer characteristics that would meet modern nutritional requirements.

Key words: bread, pumpkin, variety, semiproduct, trial baking, enrichment. 